of two storms; storms V. and VI. advanced from the Pacific, crossed California and the Rocky Mountains, and thence swept eastward over the States; and storm VIII. began its course near Chicago, ran out south-eastward to near Cape Hatteras, and then recurved in the direction of Niagara, where it died out after having traced a course nearly elliptical. It is to an exhaustive treatment of a tolerably large number of instances of these different types of storms, that we must look for the key of the mystery of the genesis, progress, and termination of the cyclone which comprehends within itself by far the major portion of all weather changes. Towards this great and perhaps not far distant result, nowhere is any meteorological system making contributions so large and so effective as is Gen. Myer through the munificent liberality of the United States Government.

\section{DIFFUSION OF COPPER IN THE ANIMAL KINGDOM}

$\mathrm{T}$ $\mathrm{HE}$ fact of the normal presence of minute quantities of copper in various members of the animal kingdom has been noticed by several chemists within the past twenty-five years. Kingzett states that he has invariably found it to be a constituent of the human brain, while Odling and Dupré, and Bergeron and Hôté have determined analytically the average amount of copper present in the liver and kidneys of human beings and domestic animals. In the latter case the average percentage of copper found was about 35 millionths. Some two years since Cloez examined the blood of a deer, and found it to contain 6 millionths of copper. The most interesting instance of the occurrence of copper in the animal creation is, however, that communicated by Prof. Church to the Royal Society in 1869. At this time he was engaged in the investigation of a peculiar, soluble, red colouring matter present in the wings of the Turaco, a bird from the West Coast of Africa. A thorough study of this pigment showed it to contain 5.8 per cent. of copper, and Prof. Church established for it the formula $\mathrm{C}_{50} \mathrm{H}_{56} \mathrm{O}_{19} \mathrm{NCu}$. Led to seek the source of this strange factor in the animal economy of the Turaco, he succeeded in detecting copper in the fruit of the Musa sapientum, which forms the chief article of the bird's diet.

To these few isolated cases of the normal assimilation of copper in the animal kingdom, Dr. M. Giunti, in the last fascicule of the Gazetta Chimica Italiana (vol. ix. p.54I), adds a number of interesting and diversified instances.

His attention was first directed to the subject accidentally by finding over one-third of $i$ per cent. of copper in the guano deposits from bats occurring in -certain Italian caves. This led to an analytical examination of the bat, the results of which showed that about four tenthousandths of the weight of the ashes of this animal consist of cupric oxirle. Still bent upon finding a more ultimate source for the metal, Giunti has subjected to analysis quantities of the insects which form the food of the bat, and in all cases he has found copper present in greater or less amount. The quantity would seem to vary in the different orders, families, and species. Aquatic insects contain less than those found on land, and the Coleoptera appear to yield the highest percentage. Thus the ashes of Anomola vitis contain o I per cent. of cupric oxide, and those of Blatta orientalis 0.826 per cent, High as this percentage seems, the amount of copper in an individual insect is infinitesimal, being, in the case of Anomala vitis, less than four-millionths of a gramme. Copper was also detected amongst other Coleoptera (such as Cetonie, Cerambur, Ateucus sacer, Leurus striatus, and notably the lava of Srillotalpa); amongst Diptera (Mosca domestica), Lepidoptera (Vanessa cardui, Piaris sinapis, Limenites camilla, \&c.), and Hymenoptera (Eschena maculatissima, Libellula depressa, Calabroni, \&c.).
Giunti has next sought to ascertain whether other insectivorous animals besides the bat are wont to assimilate the copper present in their insect. prey. This was found to be the case with all members of this class subjected to examination, such as snikes, lizards, urchins, \&c. The ashes of the latter contain from one to two ten-thousandths of copper, while the ashes of lizards contain over fifteen thousandths. In their case most of the copper is to be found in the skin of the animal.

Giunti's experiments have likewise been extended amongst the invertebrates. Various varieties of spiders; of myriapods, such as Julus terrestris; of isopods, such as Armadillidium vulgare; and of snails, have all given affirmative responses to his tests. Amongst these, Julus terrestris contains the largest amount of copper, its ashes showing a percentage of $0^{\circ} 18$.

The investigations of the Italian chemist in this novel branch of physiological chemistry are still being continued, and it is to be hoped that more extended observations will inform us of the exact nature of the rôle played by cupric compounds in the animal economy.

T. H. NORTON

NOTES

NEXT week we publish an extra number entirely devoted to an account of the life and work of $M$. Dumas, the eminent French chemist, and one of the greatest of living-Scientific Worthies. Dr. Hofmann, of Berlin, has been good enough to devote a great deal of time and research to this paper, and has treated the important subject in such detail that, owing to the pressure on our space at present, it is impossible for us to find room for this long article in the ordinary way, and we are therefore compelled to devote to it an extra number. We are sure our subscribers will give us their willing approval and support in an emergency so very special, and all will doubtless be glad to have this sketch of an eminent French chemist by so eminent a German confrère.

A PAPER has been circulated by the Perpetual Secretary of the Paris Academy giving notice that M. Maindron has been officially commissioned to coilect under their authority the archives of the Academy, in a locality belonging to the Institute. Persons. possessing documents available for that purpose are requested in the name of science kindly to send them. A fair example has been recently given by M. Bornet, whose liberality has been publicly acknowledged. M. Etienne Charavay, the expert in autographs, has recovered on behalf of the Institute a number of documents which had belonged to the Academy.

THE Society for the Promotion of Hellenic Studies, which was inaugurated in June last, held its second general meeting on Thursday, January 22, at 7 , Adelphi Terrace, Mr. C. T. Newton in the chair, when the rules drawn up by the Committee were adopted, the Bishop of Durham elected President, and other officers settled as follows:-Vice-Presidents : Lord Morley; Mr. Justice Bowen, the Dean of St. Paul's, M. Gannadius, Mr. Newton, Mr. E. Maunde Thompson, the Master of Trinity College, Cambridge, Prof. Colvin, Rev. H. F. Tozer. Praf:Sayce, Prof. Jebb, and Prof. T. K. Ingram. Council : The Bishop of Lincoln, the Dean of Westminster, the Dean of Christchunch, the Rector of Iincoln College, Oxford, Sir Jolln Lubbock (Treasurer), Sir Charles Dilke, Professors Bryce, Hórt, Kennedy, Mahaffy, B. Price, H. J. S. Smith, Tyrrell, Messrs. A. J. Balfour, M.P., Oscar Browning, J. Bywater, W. W. Capes, H. O. Coxe, T. Chenery, E. A. Freeman, Percy Gardner, George Macmillan (Hon. Sec.), Ernest Myers, D. B. Monro, J. Cotter Morìson, H. F. Pelham, F. C. Penrose, Walter Perry, J. A. Symonds, and Oscar Wilde. The objects of the Society, as stated in the outset of the Rules, are:-1. To advance the study of Greek language, literature, and art, 